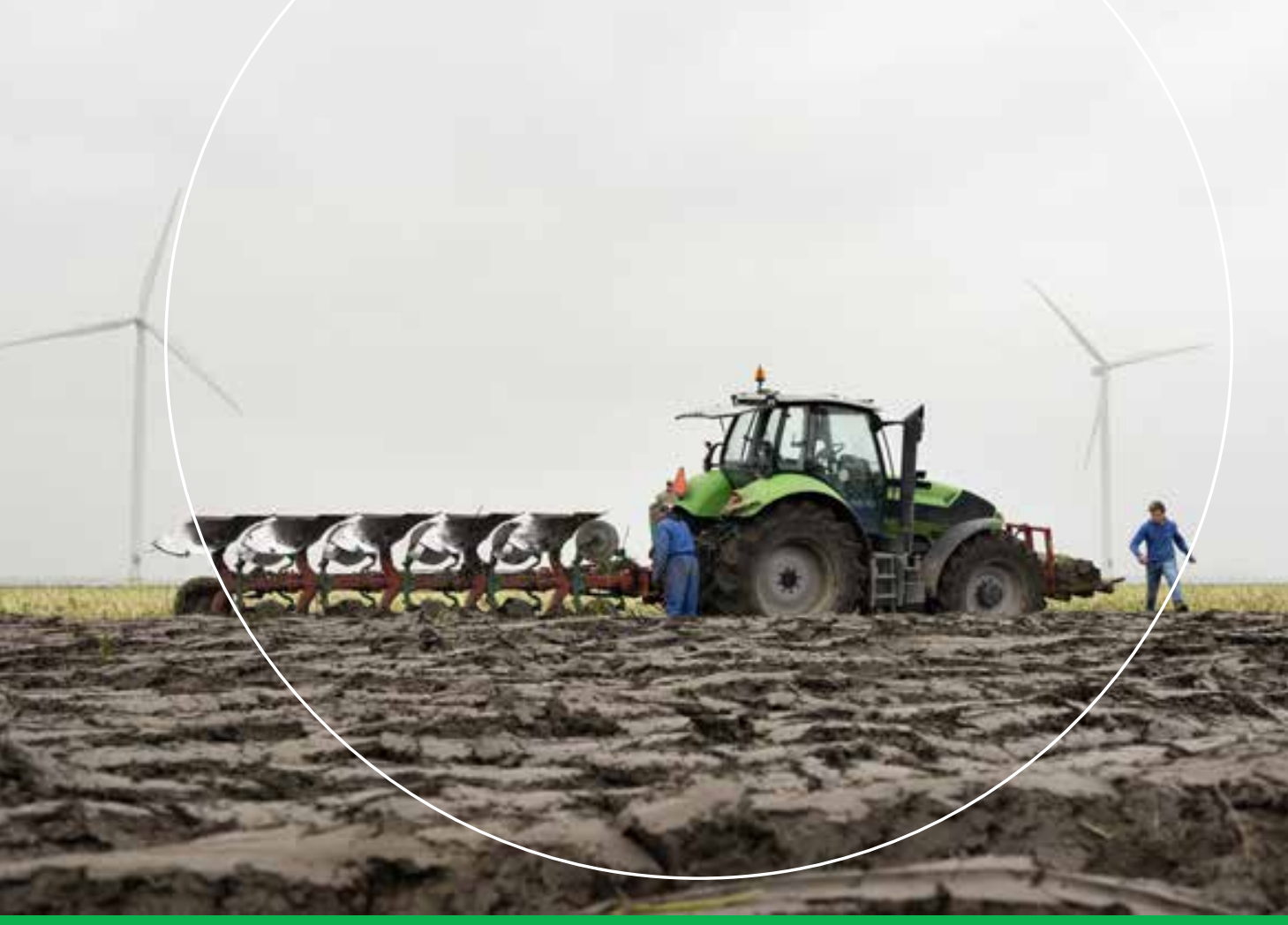

\title{
Food Economic Report 2018 of the Netherlands
}

Summary

P. Berkhout

WAGENINGEN

UNIVERSITY \& RESEARCH 



\section{Food Economic Report 2018 of the Netherlands}

\section{Summary}

P. Berkhout

This project was financed by the Dutch Ministry of Agriculture, Nature and Food Quality from the public-private partnership 'Koepel Economische Informatievoorziening'.

Wageningen Economic Research

Wageningen, January 2019

BOOKLET

ISSN 0924-0764 
Berkhout, P., 2019. Food Economic Report 2018 of the Netherlands;

Summary. Wageningen, Wageningen Economic Research, Booklet. 16 pp.; 0 fig.; 5 tab.; 0 ref.

This booklet offers an English summary of the Voedsel-Economisch Bericht 2018 and Duurzaamheid en inkomens in de land- en tuinbouw (www.agrofoodportal.com). It presents a survey of the economic state of Dutch agribusiness. Attention is paid to the development of the agricultural complex, the food industry, the retail chain, and the consumption of food. The booklet then proceeds to describe the production structure in the primary agricultural sector, profitability, and income formation as well as the environmental performance of the agricultural sector.

This publication can be downloaded at https://doi.org/10.18174/468415 or at www.wur.eu/economic-research (under Wageningen Economic Research publications).

(C) 2019 Wageningen Economic Research

P.O. Box 29703, 2502 LS The Hague, The Netherlands, $\mathrm{T}+31$ (0)70 33583 30, E communications.ssg@wur.nl, http://www.wur.eu/economic-research. Wageningen Economic Research is part of Wageningen University \& Research.

\section{(cc) BY-NC}

For its reports, Wageningen Economic Research utilises a Creative Commons Attributions 3.0 Netherlands license.

(C) Wageningen Economic Research, part of Stichting Wageningen Research, 2019

The user may reproduce, distribute, and share this work and create derivative works from it. Material by third parties which is used in the work and which are subject to intellectual property rights may not be used without prior permission from the relevant third party. The user must attribute the work by stating the name indicated by the author or licensor, but may not do this in such a way as to create the impression that the author/licensor endorses the use of the work or the work of the user. The user may not use the work for commercial purposes.

Wageningen Economic Research accepts no liability for any damage resulting from the use of the results of this study or the application of the recommendations contained in it.

Wageningen Economic Research is ISO 9001:2008 certified.

Wageningen Economic Research Booklet | Project code 2282300169

Cover photo: Anton Havelaar/Shutterstock.com 


\section{Contents}

$\begin{array}{ll}\text { Preface } & 4\end{array}$

1 The Dutch agricultural sector 5

1.1 The agricultural complex 5

$\begin{array}{lll}1.2 & \text { Food and beverage industry } & 7\end{array}$

$\begin{array}{lll}1.3 & \text { Retail chain and food consumption } & 7\end{array}$

$\begin{array}{lll}1.4 & \text { Trade in agricultural products } & 10\end{array}$

2 The agricultural and horticultural sector 11

2.1 Number of holdings 11

2.2 Labour, land, and capital 12

2.3 The sector income 13

2.4 Environmental performance 14 


\section{Preface}

This booklet provides a summary of two publications, the Food Monitor 2018 (Voedsel-Economisch Bericht) and Sustainability and income development of the primary agricultural sector 2018 (Duurzaamheid en inkomens in de land-en tuinbouw). Both publications have been commissioned by the Ministry of Agriculture, Nature and Food Quality.

The Food Monitor is the successor to the Annual Agricultural Report and offers a global survey of the Dutch food economy. Attention is paid to the development of the agricultural complex, the food industry, the retail chain, and the consumption of food. Based on the Sustainability and income development of the primary agricultural sector report, this booklet then proceeds to describe the production structure in the primary agricultural sector, profitability, and income formation as well as the environmental performance of the agricultural sector.

The full versions of both publications (in Dutch) are available online via www.agrofoodportal.com. Part of the information on this website is also available in English.

The Hague, January 2019

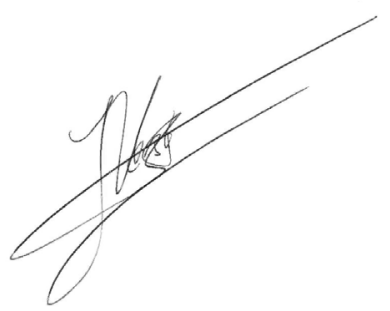

Prof.dr.ir. Jack (J.G.A.J.) van der Vorst

General Director of Social Sciences Group

Wageningen University \& Research 


\section{The Dutch agricultural sector}

\subsection{The agricultural complex}

The agricultural sector - comprising agriculture, horticulture, and fisheries - is linked closely to other parts of the economy. For example, agricultural production is virtually impossible without the provision of goods and services such as animal feed, fertiliser, energy, machinery, sheds, greenhouses, and veterinary and business services, whilst raw agricultural products require processing in the food industry, trade, and distribution before they reach the consumer table. One can view the entire set of direct and indirect activities surrounding the agricultural sector as one interrelated chain, which we often refer to as the agro (or agricultural) complex.

In this approach the primary sector and the processing industry for food are the main focal point. The size of the agricultural complex is determined by what the primary sector and processing industry need from suppliers and logistics to create the products.

Agro complex delivers more than $7 \%$ of the GDP (gross domestic product)

The added value of the total agro complex in 2016 - the most recent year for which figures are available - amounted to approximately 52 billion euros. This means the total agro complex accounts for $7.4 \%$ of the national GDP. Since 2010, the share of the national total has hovered between 7 and $7.5 \%$. The share has grown slightly in 2016 when compared with 2015.

The arable complex is, in terms of added value, the most important within the total agro complex. This is due to the large share of imports of coffee, tea, and cocoa, and of vegetable oils and fats. The import of animal feed raw materials is also allocated to the arable complex. The land-based livestock farming complex comes in second place. 
Employment in the entire agricultural complex has grown during recent years, reaching about 626,000 employment years in 2016 (Table 1), which represents $8.7 \%$ of the national total. With the exception of primary production, employment has grown in all the links of the complex since 2010 .

Table 1 Gross value added and employment in the Dutch agricultural complex, 2010 and 2016 a)

\begin{tabular}{|c|c|c|c|c|}
\hline & $\begin{array}{l}\text { Added } \\
\text { value } \\
\text { ( } x \text { billion } \\
\text { euros) }\end{array}$ & $\begin{array}{l}\text { Added } \\
\text { value } \\
\text { ( } x \text { billion } \\
\text { euros) }\end{array}$ & $\begin{array}{l}\text { x } 1000 \\
\text { annual } \\
\text { labour } \\
\text { units } \\
\end{array}$ & $\begin{array}{l}\text { X } 1000 \\
\text { annual } \\
\text { labour } \\
\text { units }\end{array}$ \\
\hline & 2010 & 2016 & 2010 & 2016 \\
\hline $\begin{array}{l}\text { Total - domestic and imported } \\
\text { agricultural raw materials complex }\end{array}$ & 43.2 & 52 & 575.6 & 626.0 \\
\hline Share in national total (GDP) & $7.6 \%$ & $7.4 \%$ & $8.2 \%$ & $8.7 \%$ \\
\hline $\begin{array}{l}\text { Totals - imported agricultural raw } \\
\text { materials complex }\end{array}$ & 15.1 & 18.8 & 174.1 & 193.2 \\
\hline Share in national total & $2.7 \%$ & $2.7 \%$ & $2.5 \%$ & $2.7 \%$ \\
\hline $\begin{array}{l}\text { Total - domestic agricultural raw } \\
\text { materials complex }\end{array}$ & 28.1 & 33.2 & 401.5 & 432.8 \\
\hline Share in national total & $4.9 \%$ & $4.7 \%$ & $5.7 \%$ & $6.0 \%$ \\
\hline Primary production & 9.1 & 9.8 & 164.7 & 162.7 \\
\hline Processing & 4.2 & 6.8 & 54.7 & 67.2 \\
\hline Supply & 11.8 & 12.7 & 144.9 & 162.0 \\
\hline Distribution & 3.0 & 3.9 & 37.2 & 40.9 \\
\hline
\end{tabular}

a) The share of added value is calculated as a percentage of GDP and not as a percentage of the national added value.

Source: CBS (Statistics Netherlands) - processed by Wageningen Economic Research.

Export makes a significant contribution to gross value added (GVA) and employment in the agricultural complex

An important part of the activities of the agricultural complex is related to export of processed and raw agricultural materials. Export contributes about three quarters of GVA and employment in the sector of the agricultural complex based on domestic raw materials. The dependence on export throughout the entire agricultural complex is slightly lower at $72 \%$. 


\subsection{Food and beverage industry}

Measured by sales and employment, the food industry is the largest branch of industry. In 2017, the number of companies in the food industry rose to 5,450 ; they offered employment to 124,000 people. Almost one in six industrial employees works in the food industry. The beverage industry included 605 companies in 2017, with employment for 7,100 people. Several industrial sectors are included in these figures, from fruit and vegetable processing to abattoirs, meat products industry, bakeries, and baked goods. The tobacco industries are not included.

When measuring by net sales, the meat-processing industry and the dairy-processing industry are the largest sectors within the food industry, with shares of $16 \%$ and $17 \%$ respectively. It is striking that these sectors consist of one giant and a number of smaller companies, some three quarters of which are micro businesses (companies with up to 10 employees). In the dairy industry, $24 \%$ of companies are made up of small and medium-sized enterprises (SMEs) (less than 250 employees, more than 9 employees); for meat this share is $19 \%$.

\subsection{Retail chain and food consumption}

In 2017, the total foodstuff turnover through all sales channels in the Netherlands reached 58 billion euros (Table 2). That sum includes retail sales (supermarkets and other retail outlets, e.g. markets and specialised businesses), and the food service sector (hotels and restaurants, catering, leisure, and sales points "on the move"). Food and drink turnover in the retail industry in 2017 amounts to roughly 40 billion euros. Out of all food turnover, 30.5 billion euros is realised by supermarkets. This makes them the main sales channel for food and drinks. The turnover of supermarkets has increased by nearly 1 billion euros when compared with 2016. Food service accounts for almost one third of all turnover. In total, more than 19 billion euros was spent in the hospitality industry, recreation, catering, and motorway retail outlets; an increase of 0.8 billion euros when compared to 2016 . The following 
table is an overview of food and drink turnover by type of sales channel. The boundaries between the types of sales channels have become less clear over the years. For instance, retailers in the food sector more often have opportunities to develop food service activities in their store and shopping areas are also frequently included in catering locations.

Table 2 Food and drink turnover in the Netherlands, 2016 and 17, in billions of euros

\begin{tabular}{lrr} 
& 2016 & 2017 \\
Supermarkets & 29.6 & 30.5 \\
\hline Small retail and online retail (incl. temporary retail locations) a) & 8.2 & 8.6 \\
\hline Food service, b) of which & 18.3 & 19.1 \\
\hline Hospitality & 11.3 & 11.9 \\
\hline Sport and recreation c) & 1.3 & 1.3 \\
\hline Catering & 3.2 & 3.3 \\
\hline Roadside d) & 2.5 & 2.6
\end{tabular}

a) Online delivery service by supermarkets is, whenever possible, included in online retail.

b) Including online delivery service of meals.

c) Expenditures in sports facilities, recreation parks, amusement parks, etc.

d) Expenditures in petrol stations and catering in retail and (public) transport.

Source: Foodstep (food service), CBS (supermarkets), FSIN (other). Editing: Wageningen Economic Research.

The large supermarket chains such as Ahold (Albert Heijn), Jumbo, Lidl, and Aldi buy independently, while the smaller chains are members of the wholesale purchasing cooperative Superunie. Ahold holds top rank for turnover and market share in the Netherlands. In 2017, Ahold realised more than 13 billion euros in turnover and Jumbo comes in a safe second, with a turnover of 7 billion euros. Together, Albert Heijn/AH ventures and Jumbo control $54 \%$ of the market.

\section{Increased household expenditure on food}

In 2017, Dutch households spent around 310 billion euros on food, semi-luxury foods and beverages, tobacco, consumer durables, energy, water, fuel, and services, including hotels, restaurants, and catering. Almost 46 billion euros was spent on food and semi-luxury foods (Table 3). From that sum, over 29 billion euros of the expenditure was 
on foodstuffs, e.g. dairy products, meat and fish, potatoes, vegetables and fruit, and bread. The remaining expenditure was on semi-luxury items such as ice creams, sweets, beverages, and tobacco. Expenditure on food in catering and leisure is included in those for services and is not indicated in this section.

Table 3 Household consumer expenditure (billions of euros) a) 2012-2015

\begin{tabular}{|c|c|c|c|c|c|}
\hline & 2013 & 2014 & 2015 & 2016 b) & 2017 b) \\
\hline Foodstuffs & 26.8 & 27.0 & 27.8 & 28.5 & 29.3 \\
\hline $\begin{array}{l}\text { Semi-luxury foods, } \\
\text { beverages, and tobacco c) }\end{array}$ & 15.5 & 15.7 & 15.9 & 16.1 & 16.4 \\
\hline $\begin{array}{l}\text { Total on food and semi- } \\
\text { luxury items d) }\end{array}$ & 42.3 & 42.7 & 43.7 & 44.6 & 45.8 \\
\hline $\begin{array}{l}\text { Total consumer expenditure } \\
\text { on goods and services }\end{array}$ & 284.4 & 287.5 & 294.1 & 300.4 & 310.3 \\
\hline $\begin{array}{l}\text { Share (\%) foodstuffs and } \\
\text { semi-luxury foods, drinks, } \\
\text { and tobacco }\end{array}$ & 14.8 & 14.9 & 14.9 & 14.8 & 14.7 \\
\hline
\end{tabular}

a) Compared to actual prices.

b) The expenditure in euros is calculated on the basis of published indices and changes in value.

c) Including tobacco. According to the trade association for the tobacco retail outlets, spending on tobacco amounted to more than 4.2 billion euros in 2016 .

d) Relates to spending by consumers through trade or directly. Expenditure in hospitality and catering is not included.

Source: CBS - processed by Wageningen Economic Research.

Consumption of foodstuffs from sustainable and organic production continues to grow

The total consumer spending on sustainable food amounted to 4.5 billion euros in 2017: an increase of $19 \%$ when compared with 2016 . The share of sustainable food within the total food spending increased from $10 \%$ in 2015 to $11 \%$ in 2017 . Across all product groups, consumers have more often chosen to include an organic product as part of their basic groceries in recent years. Products which are produced under other sustainability certification systems, such as Beter Leven (quality label for animal welfare), Aquaculture Stewardship Council (ASC, a 
quality label for farmed fish), and Fair Trade, also account for an increasing proportion of the range. The turnover of products with a sustainability logo rose by $68 \%$ between 2013 and 2016. These products can be slightly more expensive than their equivalents from the common production systems.

\subsection{Trade in agricultural products}

Break in the trend in the growth of exports

In 2017, the agricultural sector exported goods to the value of 90.1 billion euros. The amount of the Dutch agricultural export for 2018 is estimated at 90.3 billion euros. That is $0.2 \%$ more than in 2017 and a trend break in comparison with the growth in the previous two years (more than $4 \%$ in 2016 and over 6\% in 2017). In 2017, the Netherlands is again the second largest agricultural exporter in the world, after the United States of America (USA). Germany, Brazil, and China round out the top 5 of the most important export countries for 2017. A striking difference between the countries is that, in this top 5, Brazil and the Netherlands are net exporters, while the United States, Germany, and especially China import more than they export. Brazil is actually the largest net agricultural exporter in the world, followed by Argentina, with the Netherlands in third place.

In 2017 , about $78 \%$ of Dutch agricultural exports went to EU countries. This percentage has remained fairly constant in recent years. Germany, Belgium, the United Kingdom, and France accounted for approximately $55 \%$ of the exports. The most important export products are vegetables and fruit, live animals and meat, and flowers and plants.

Import value of agricultural products in the Netherlands increases Imports in 2018 are estimated at 61.4 billion euros, which is $0.5 \%$ higher than the final figure of 2017. The share of imports from EU countries has remained fairly stable at around $60 \%$. The most important source countries for imports from within the EU are Germany, Belgium, France, and the United Kingdom. The main import source countries outside the EU are Brazil, the United States (soy), and Ivory Coast (cocoa). 


\section{The agricultural and horticultural sector}

\subsection{Number of holdings}

The number of agricultural and horticultural companies decreased by more than 800 , to 54,800 in 2017 , a decrease of $1.5 \%$ (Table 4 ). That is less than the long-term average of $2 \%$ to $3 \%$ per year. In 2016, due to changes in the registration of the agricultural and horticultural companies, the number of farms saw a sharp one-time decline $(13 \%)$. The most important change is that companies not listed in the trade register (Chamber of Commerce) with agrarian activity, are no longer included in the agricultural census.

Table 4 Developments in the numbers of holdings and employees, and total area of farmland from 2000 onwards

\begin{tabular}{lrrrrr} 
& 2000 & 2005 & 2010 & 2016 & 2017 \\
$\begin{array}{l}\text { Number of agricultural and } \\
\text { horticultural farms (x 1,000) }\end{array}$ & 97,389 & 81,750 & 72,324 & 55,681 & 54,840 \\
\hline Number of workers (x 1,000) & 280.9 & 235.7 & 212.0 & 173.0 & \\
\hline Area of farmland (x 1,000 ha) & 1975.5 & 1937.7 & 1872.3 & 1796.3 & 1790.0 \\
\hline
\end{tabular}

Source: CBS (Statistics Netherlands) agricultural census, processed by Wageningen Economic Research.

In the least land-based sectors - greenhouse horticulture and intensive livestock farming - the decrease in the number of holdings in 2017 is at the level of the 2000-2015 period. This also applies to arable farming. For horticultural farming and grazing cattle (including dairy farming), the decrease in 2017 (around 1\%) lies below the long-term average (2000-2015). The number of combined holdings has, after years of sharp decline (6\% per year between 2000 and 2015), increased over the past two years. 
In 2017, the acreage of agricultural land dropped to 1.79 million hectares. This corresponds to a decrease of nearly $0.4 \%$ and is in line with the long-term average. The reduction of the agricultural land acreage is entirely made up of (temporary and natural) pasture that is partly offset by an increase in the acreage of arable and horticultural open land.

\subsection{Labour, land, and capital}

The total number of regular active labourers in primary agriculture and horticulture decreased in 2017 by more than 2,300, to 170,400. The decrease of $1.3 \%$ in 2017 is well below the multi-year average (20002015 ) of $2.7 \%$. In 2016, there was a sharp reduction in the work force $(-23,000$ or $-7 \%)$ which was mainly caused by changes in the registration of agricultural and horticultural companies.

Around $70 \%$ of the permanent labour force is made up of families. 120,000 of the regularly active (permanent) labour force are now made up of families (farmers, spouses, and family members that assist), or $71 \%$. Over the years (from 2000), the share has barely changed. The non-family labour force amounts to 50,000 in 2017, and is only slightly below the number in the previous two years. The flexible workers (temporary agency workers and staff with temporary contracts) are not included in these figures. The permanent labour force usually has fulltime year-round jobs, while the use of flexible labour, especially in the open-land sectors, is limited to the peak periods. This means that the number of flexible labourers - even approximately - is hard to determine. During harvest/peak periods, large numbers of people may be at work, but only for (very) short periods of time.

Balance sheet value of agriculture and horticulture, 3 million euros in 2017

The average balance sheet value of Dutch agricultural and horticultural businesses was 3 million euros at the end of 2017, +150,000 euros when compared with 2017 . More than 70 percent $(71 \%)$ of that is financed with in-house capital. 
Since the beginning of this decade (2010), the average book value of agricultural and horticultural holdings increased by around 0.5 million euros, mainly due to an increased average farm size and higher farmland prices. In the same period the solvency rate (part that is financed with in-house capital) increased from $67 \%$ to $71 \%$. By the end of 2017 , the land represented $56 \%$ of the total balance sheet value, compared to $46 \%$ in 2010 .

\subsection{The sector income}

The average company income for the agricultural and horticultural companies in 2018 is estimated at about 42,000 euros per unpaid annual work unit (AWU). That is a decrease of almost 30,000 euros when compared to the historical peak year of 2017. Also, the income is lower than the multi-year average income of 51,000 euros over the period 2013-2017. Only the tree nursery sector can rely on income growth. Sow farms are the hardest hit, where the income ends up deep in the red in 2018. Due to the hot, dry summer of 2018, the differences in income between individual entrepreneurs will be greater than normal.

Pig farmers are faced with significantly lower prices for piglets and fatteners, which means their income ${ }^{1}$ ends up in red. Dairy farmers will see their income ${ }^{1}$ cut by more than half due to a combination of the higher cost of livestock feed and lower dairy yields.

For arable farmers, the income ${ }^{1}$ in the harvest year 2018 is estimated to be equal to last year. The drought and potential for watering (or lack thereof) account for large regional differences in crop yields and incomes between the companies. In greenhouse horticulture there are drops both in the glasshouse edibles as well as floriculture incomes ${ }^{1}$ due to the fact that costs, particularly energy, have increased more than the proceeds. An important exception comes from the growers of cucumbers, who realised higher incomes due to high cucumber prices.

1 Income holding per unpaid annual work unit 
While the average agricultural and horticultural company in 2017 received a market-based payment for the use of its own labour and equity for the first time, the profitability drops to 96 euros of income per 100 euros in costs in 2018. Within agriculture and horticulture there are large differences in income regarding the average each year, both between and within the different business types.

\subsection{Environmental performance}

The environmental impact of the primary agriculture and horticulture sector is visible and measurable through different environmental indicators. There is wide ranging variation between developments connected with each environmental issue.

The agricultural sector is the main source for the emission of ammonia; ammonia is released in stables and in the use and storage of manure and fertiliser. The ammonia emissions from stables and in the storage of animal manure make up the lion's share of ammonia emissions. Since 2010, ammonia emissions are virtually stable at a level of around 110-115 million $\mathrm{kg}$ (Table 5). For the $2020-2030$ period, a $13 \%$ decrease in ammonia emissions from all sources has been agreed in the EU when compared to 2005 (133 million $\mathrm{kg}$ ). This objective has already been achieved.

The use of crop protection agents has shown virtually no downward trend in the last few years. For years, the sales of plant protection products have been hovering around 10 million $\mathrm{kg}$ of active substance per year with a slightly decreasing trend in recent years. In 2016, sales increased from 8.7 to 9.5 million $\mathrm{kg}$. More than $40 \%$ of the products are used as fungicide and a little under $30 \%$ are used against weeds (herbicides, including glyphosate). The fluctuations in use depend strongly on the weather, as in years with humid summers, the impact of mould is higher than in dry years. A cold and therefore slow start to the growing season also affects use, because the development of diseases and pests is slower in those instances. 
In addition to use in absolute quantities, the environmental impact of the products used per $\mathrm{kg}$ of active substance is an important indicator. Thanks to an ongoing clean-up of relatively damaging agents, the environmental impact has greatly diminished during the 2007-2012 period. More up-to-date figures are not available.

Table 5 Development of the environmental impact of agriculture and horticulture, 2000-2016

\begin{tabular}{lcccccr} 
& 2000 & 2005 & 2010 & 2015 & 2016 \\
$\begin{array}{l}\text { Use of crop protection agents (in } \\
\text { million kg of active substance) }\end{array}$ & 9.644 & 9.309 & 9.288 & 8.698 & 9.511 a) \\
\hline $\begin{array}{l}\text { Greenhouse gas emissions (in } \\
\text { billion } \mathrm{CO}_{2} \text { equivalents, IPPC2013) }\end{array}$ & 28.8 & 26.4 & 29.1 & 27.4 & 27.2 \\
\hline $\begin{array}{l}\text { Surplus of nitrogen (N, kg per } \\
\text { hectare) }\end{array}$ & 183 & 142 & 113 & 131 & 140 \\
\hline $\begin{array}{l}\text { Surplus of phosphates ( } \mathrm{P}_{2} \mathrm{O}_{5}, \mathrm{~kg} \text { per } \\
\text { hectare) }\end{array}$ & 23 & 16 & 11 & 3 & 8 \\
\hline \begin{tabular}{l} 
Ammonia emissions (in million kg) \\
\hline
\end{tabular} & 161 & 136 & 118 & 111 & 110 \\
\hline
\end{tabular}

a) 2016

Sources: Nefyto - RIVM (Dutch National Institute for Public Health and the Environment)/CBS, Milieucompendium (Environment Compendium), various years.

The emission of greenhouse gases has sharply declined since 1990, but has been fairly stable in recent years. In 2016, emissions are almost equal to the emissions from 2015. The share of agriculture and horticulture in total greenhouse gas emissions in the Netherlands is around $12 \%$ to $14 \%$.

On July 10, 2018 the Klimaatakkoord op hoofdlijnen (outline of the climate agreement) was presented, which primarily focuses on achieving climate goals by 2030. For agriculture and land use, a target of 3.5 megatons of $\mathrm{CO}_{2}$-equivalent emission reduction in 2030 compared with 1990 is considered feasible.

The surplus of nitrogen and phosphate per hectare has very greatly diminished as a result of the export of manure, decrease in fertiliser use, and lower phosphate levels in feed and in turn, manure. The total 
phosphate and nitrogen production is tied to a ceiling: per year, the excretion of nutrients may not exceed 173 million kilograms of phosphate and 504 million kilograms of nitrogen (including gaseous losses). Both targets were still met in 2014, but in 2015 and 2016 the ceiling for phosphate was exceeded. This excess was mainly caused by the higher phosphate production in dairy farming. The amount of phosphate in animal manure in 2017 is again lower than the ceiling set by the EU, thanks to the measures taken to reduce the phosphate production in dairy farming. 

The mission of Wageningen University and Research is "To explore the potential of nature to improve the quality of life". Under the banner Wageningen University \& Research, Wageningen University and the specialised research institutes of the Wageningen Research Foundation have joined forces in contributing to finding solutions to important questions in the domain of healthy food and living environment. With its roughly 30 branches, 5,000 employees and 10,000 students, Wageningen University \& Research is one of the leading organisations in its domain. The unique Wageningen approach lies in its integrated approach to issues and the collaboration between different disciplines.

Wageningen Economic Research

P.O. Box 29703

2502 LS Den Haag

The Netherlands

E communications.ssg@wur.nl

www.wur.eu/economic-research

\section{BOOKLET}

ISSN 0924-0764 